\title{
Efek Ratchet pada Anggaran Pemerintah Daerah: Studi pada Satuan Kerja Perangkat Daerah Pemerintah Provinsi Daerah Istimewa Yogyakarta
}

\author{
Anindyo Aji Susanto", Abdul Halim ${ }^{2}$ \\ 1) Fakultas Ekonomi, Universitas Pembangunan Nasional "Veteran” Yogyakarta \\ 2) Fakultas Ekonomika dan Bisnis, Universitas Gadjah Mada
}

\begin{abstract}
Ratchet effect defined as form of budget setter's behavioral bias in budget setting or budget planning process. Ratchet effect occurs when budget setter use prior period performance as basis to determine the upcoming budget as a consequences of the dynamic incentives problems in agency relation context. Lee and Plummer (2007) documented ratchet effect in public sector budgeting on performance based budgeting implementation. This study aims to find whether ratchet effecct occur in public sector budgeting, especially in Indonesian local government budgeting.
\end{abstract}

This study use Local Government Task Force (SKPD) of Yogyakarta Special Region Province Government as research object for research period between 2012 to 2015. Selection of sample derived using purposive sampling to 31 SKPD and generates 17 sample which has Region Original Revenue (PAD) component and so 28 sample which has Direct Expenditure component in each of it's budget structure. Total observed object used to examine ratchet effect in PAD budgeting is 68 observation and so forth 112 observation used to examine ratchet effect in Direct Expenditure budgeting. Multiple Linear Regresion used to test the hypotheses. The result shows that ratchet effect occurs in both PAD and Direct Expenditure budgeting, so all research hypotheses statistically accepted. This research generate evidence the occurence of ratchet effect in local government budgeting.

\begin{abstract}
Abstrak: Efek roda gigi searah ("ratchet") merupakan bentuk bias perilaku penyusun anggaran dalam proses penentuan atau perencanaan anggaran. Efek ratchet muncul ketika perencana angggaran menentukan target anggaran berdasarkan capaian kinerja anggaran periode sebelumnya sebagai akibat adanya persoalan insentif dinamik dalam konteks hubungan keagenan. Lee dan Plummer (2007) mendokumentasikan terjadinya efek ratchet pada penganggaran sektor publik dalam implementasi model penganggaran berbasis kinerja. Penelitian ini dilakukan untuk mengetahui adanya efek ratchet dalam penganggaran sektor publik, khususnya dalam penganggaran pemerintah daerah di Indonesia.

Penelitian ini menggunakan sampel Satuan Kerja Perangkat Daerah (SKPD) di lingkup Pemerintah Provinsi Daerah Istimewa Yogyakarta pada periode 2012-2015. Pemilihan sampel dilakukan dengan metode sampel purposif atas 31 SKPD dan menghasilkan 17 sampel SKPD yang memiliki komponen Pendapatan Asli Daerah (PAD) dan 28 sampel SKPD yang memiliki komponen Belanja Langsung dalam struktur anggarannya. Jumlah keseluruhan observasi yang digunakan untuk menguji efek ratchet dalam penganggaran PAD berjumlah 68 observasian dan jumlah observasi untuk menguji efek ratchet dalam penganggaran Belanja Langsung berjumlah 112 observasian. Analisis yang digunakan untuk pengujian hipotesis adalah analisis regresi linier berganda. Hasil penelitian menunjukkan bahwa efek ratchet terjadi dalam penganggaran PAD dan Belanja Langsung, sehingga semua hipotesis penelitian ini terdukung secara statistik. Hasil penelitian ini membuktikan adanya efek ratchet dalam penyusunan anggaran pemerintah daerah.
\end{abstract}

Kata kunci: Efek Ratchet, Anggaran Berbasis Kinerja, Penganggaran Pemerintah Daerah, Pendapatan Asli Daerah, Belanja Langsung.

\footnotetext{
${ }^{1}$ Corresponding author's email: anindyoajisusanto@gmail.com
} 


\section{Pendahuluan}

Efek ratchet merupakan bentuk bias perilaku yang hampir selalu muncul dalam hubungan keagenan antara prinsipal dan agen (Indjejikian \& Nanda, 1999). Efek ratchet muncul ketika target kinerja agen ditetapkan oleh prinsipal melalui proses negosiasi dengan menggunakan informasi kinerja periode sebelumnya. Beberapa literatur ekonomi menyebut proses yang demikian dengan istilah ratchet atau ratcheting. ${ }^{2}$ Prinsipal menggunakan informasi kinerja periode sebelumnya untuk menetapkan target kinerja agen dan menentukan alokasi sumber daya organisasi melalui penganggaran. Keunggulan relatif agen menciptakan asimetri informasi yang menyebabkan prinsipal keliru menilai kapasitas riil kinerja agen (Leone \& Rock, 2002) dan memberi ruang bagi agen untuk menurunkan kapasitas kinerja (Bouwens \& Kroos, 2011; Chow, Cooper, \& Haddad, 1991; Indjejikian \& Nanda, 1999), menciptakan slack (Marlowe, 2009) dan memodifikasi komponen akrual diskresioner atau manipulasi aktivitas riil (Bouwens \& Kroos, 2011).

Informasi kinerja periode sebelumnya menyediakan informasi yang relevan bagi prinsipal jika varian kinerja (perbedaan antara realisasi dengan target yang diharapkan)

\footnotetext{
${ }^{2}$ Istilah ratchet atau ratcheting merupakan istilah asing yang belum penulis temukan padanan katanya dalam Bahasa Indonesia. Literatur ekonomi menggunakan istilah ratchet (Fisher, Frederickson, \& Peffer, 2002; Weitzman, 1980) atau ratcheting (Aranda \& Arellano, 2010; Bouwens \& Kroos, 2011; Leone \& Rock, 2002) yang terjadi dalam proses penentuan anggaran (budget ratchet) atau kinerja (target ratcheting). Istilah ratchet atau ratcheting menjelaskan peristiwa yang terjadi pada subjek (ex-ante) sedangkan frasa efek ratchet menjelaskan kondisi subjek setelah tindakan atau peristiwa ratchet atau ratcheting terjadi pada subjek (expost). Penelitian ini menggunakan istilah efek ratchet karena kesesuaian penggunaan istilah tersebut dengan konteks penelitian.
}

bersifat permanen (Aranda \& Arellano, 2010). Penggunaan informasi kinerja periode sebelumnya dalam proses penentuan target kinerja dapat merevisi keyakinan prinsipal mengenai kapasitas kinerja agen dalam rentang yang mencakup beberapa periode (Fisher, Frederickson, \& Peffer, 2006).

Penelitian mengenai efek ratchet dalam penganggaran organisasi sektor publik telah dilakukan dengan berbagai konteks. Penelitian Lee dan Plummer (2007) menjelaskan adanya efek ratchet dalam anggaran sekolah di Texas. Marlowe (2009) meneliti mengenai efek ratchet yang terjadi dalam konteks pemerintahan kota di negara bagian Minnesota, Amerika. Abdullah dan Juanita (2016) menemukan bahwa budget ratcheting memoderasi hubungan antara pendapatan sendiri dengan belanja daerah dalam studi yang dilakukan di pemerintah kabupaten/kota di Aceh, Indonesia.

Anggaran pemerintah di Indonesia merupakan salah satu instrumen dalam pengukuran kinerja pemerintah yang diukur dengan membandingkan realisasi anggaran dengan anggaran yang direncanakan (Bawono, Halim, \& Lord, 2012). Pengukuran kinerja dilakukan oleh badan legislatif untuk mengambil keputusan mengenai alokasi anggaran tahun berikutnya pada setiap bagian organisasi pemerintahan daerah (Satuan Kerja Perangkat Daerah/SKPD). ${ }^{3}$ Proses tersebut menegaskan keterlibatan eksekutif (agen) dan legislatif (prinsipal) dalam bentuk kontrak (incomplete contract) yang menjadi alat bagi legislatif untuk mengawasi pelaksanaan anggaran oleh eksekutif (Halim \& Abdullah, 2010).

Efek ratchet pada proses penyusunan anggaran organisasi pemerintahan merupakan

\footnotetext{
${ }^{3}$ Peraturan Pemerintah Nomor 8 Tahun 2006 tentang Laporan Kinerja Pemerintah Daerah (LAKIP)
} 
penjelasan atas pertumbuhan anggaran dari waktu ke waktu. Pertumbuhan anggaran dari waktu ke waktu kurang lebih sekedar mengikuti norma klasik, yaitu "realisasi anggaran tahun sebelumnya ditambah tingkat pertumbuhan tertentu" (Lee \& Plummer, 2007; Marlowe, 2009). Hal ini menghasilkan implikasi berupa kecenderungan untuk produksi berlebihan pada barang dan jasa publik, effort reduction dan menggunakan anggaran untuk aktivitas yang tidak penting menjelang akhir tahun anggaran (Lee \& Plummer, 2007).

Pemerintah Provinsi Daerah Istimewa Yogyakarta (DIY) merupakan salah satu pemerintah daerah di Indonesia yang memiliki catatan prestasi baik. Anggaran Pendapatan dan Belanja Daerah (APBD) Pemprov DIY meningkat dari waktu ke waktu. APBD Pemprov DIY di sisi pendapatan daerah meningkat rata-rata sebesar $20,64 \%$ per tahun selama kurun waktu 2010 - 2015 dan 16,24\% per tahun di sisi Pendapatan Asli Daerah (PAD). PAD Pemprov DIY meningkat dari semula sebesar Rp. 867 Miliar pada tahun 2010 menjadi Rp.1,5 Triliun pada tahun 2015. Rata-rata realisasi PAD selama kurun waktu melampaui target anggaran yang direncanakan pada kisaran 3-12\%. ${ }^{4}$ Perkembangan yang terjadi pada komponen pendapatan di APBD Pemprov DIY ini mengindikasikan bahwa anggaran pemerintah di sisi pendapatan cenderung underforecast. Hal demikian terjadi dalam perencanaan pendapatan pemerintah, karena pemerintah daerah cenderung menciptakan slack di sisi pendapatan untuk memudahkan pencapaian target anggaran (Abdullah \& Nazry, 2015; Marlowe, 2009).

Pada kurun waktu yang sama, belanja daerah Pemprov DIY tumbuh rata-rata 22,31\%

\footnotetext{
${ }^{4}$ Kajian Pendapatan Asli Daerah DIY (Kerjasama DPPKAD DIY dengan P2EB UGM Tahun 2016)
}

per tahun selama periode 2010 - 2015. Belanja daerah semula sebesar Rp. 1,5 Triliun pada tahun 2010, meningkat menjadi Rp 3,4 Triliun pada tahun 2015. Namun demikian, realisasi belanja daerah cenderung fluktuatif pada kisaran 86 - 92\% dari anggaran yang direncanakan. Situasi ini mengindikasikan bahwa capaian realisasi anggaran memerlukan peningkatan dari sisi perencanaan dan pelaksanaan anggaran. Ruang lingkup pada APBD Pemprov DIY inilah yang menarik menarik minat peneliti untuk mengetahui keberhasilan perubahan paradigma penganggaran pemerintah dengan penerapan anggaran berbasis kinerja dapat mengurangi terjadinya bias perilaku anggaran pemerintah dalam bentuk efek ratchet.

\section{Kajian Literatur dan Pengembangan Hipotesis}

\section{Anggaran Berbasis Kinerja pada Pemerintah Daerah di Indonesia}

Salah satu upaya perbaikan proses penganggaran pemerintahan di Indonesia adalah penerapan anggaran berbasis prestasi kerja. Penerapan sistem anggaran berbasis kinerja dengan kriteria evaluasi kinerja dilakukan untuk menghindari duplikasi dalam penyusunan rencana kerja dan anggaran di tingkat kementerian negara/lembaga maupun perangkat daerah. Penyatuan sistem akuntabilitas kinerja dalam sistem penganggaran diwujudkan dengan sistem penyusunan rencana kerja dan anggaran kementerian negara/lembaga/perangkat daerah.

Peraturan Pemerintah No 8/2006 mengenai Laporan Akuntabilitas Kinerja Pemerintah (LAKIP) merupakan peraturan utama yang menjadi acuan pemerintah daerah dalam penyusunan evaluasi kinerja dan diikuti dengan Permendagri No 65 Tahun 2007 dan Permendagri No 73 Tahun 2009 mengenai 
evaluasi kinerja pemerintah daerah berikut penyusunan peraturan daerah yang memberikan legitimasi ketercapaian kinerja pemerintah daerah pada suatu periode anggaran.

\section{Penyusunan Anggaran Pemerintah Daerab}

Anggaran Pendapatan dan Belanja Daerah/APBD adalah rencana keuangan tahunan pemerintahan daerah yang dibahas dan disetujui bersama oleh pemerintah daerah dan DPRD, dan ditetapkan dengan peraturan daerah. APBD disusun dengan mengacu pada Rencana Kerja Pemerintah Daerah (RKPD). Siklus penyusunan APBD diawali dengan penyampaian kebijakan umum (KUA) APBD sebagai landasan penyusunan rancangan APBD kepada DPRD. Berdasarkan kebijakan umum APBD yang telah disepakati dengan DPRD, Pemerintah Daerah bersama DPRD membahas Prioritas dan Plafon Anggaran Sementara (PPAS) untuk dijadikan acuan penyusunan anggaran bagi setiap Satuan Kerja Perangkat Daerah (SKPD). Kepala SKPD selanjutnya menyusun Rencana Kerja dan Anggaran SKPD (RKA-SKPD) berdasarkan prestasi kerja yang akan dicapai. Rencana Kerja dan Anggaran ini disertai dengan prakiraan belanja untuk tahun berikutnya setelah tahun anggaran yang sudah disusun. Rencana Kerja dan Anggaran ini kemudian disampaikan kepada DPRD untuk dibahas dalam pembicaraan pendahuluan RAPBD.

\section{Efek Ratchet Pada Penganggaran Pemerintah Daerah}

Efek ratchet dalam penyusunan anggaran muncul dalam bentuk perilaku oportunistik eksekutif dengan memodifikasi realisasi anggaran tahun berjalan menjelang akhir tahun anggaran. Model keagenan analitis menyatakan bahwa superior/prinsipal dapat menggunakan kinerja subordinat/agen pada periode berjalan untuk memperbaharui keyakinan mengenai kinerja periode mendatang (Fisher et al., 2006; Weitzman, 1980). Bentuk keyakinan tersebut tertuang dalam proses negosiasi pada anggaran periode mendatang (Fisher et al., 2006). Dengan adanya efek ratchet, anggaran pada periode mendatang akan sama dengan anggaran periode berjalan ditambah penyesuaian (efek ratchet) yang ditentukan berdasarkan selisih antara luaran aktual (realisasi) dibandingkan dengan anggaran pada periode berjalan (Aranda \& Arellano, 2010; Chow et al., 1991; Fisher et al., 2006; Lee \& Plummer, 2007; Marlowe, 2009; Weitzman, 1980).

Penelitian ini dilakukan untuk mengetahui efek ratchet pada penganggaran APBD dalam 2 komponen APBD, yaitu Pendapatan Daerah dan Belanja Daerah. Pembiayaan daerah tidak menjadi fokus penelitian karena besaran pembiayaan daerah ditetapkan berdasarkan perhitungan surplus/defisit APBD yang merupakan selisih pendapatan daerah dikurangi belanja daerah, sehingga besaran pembiayaan daerah sangat tergantung pada kemampuan pemerintah dalam mengelola 2 komponen utama APBD, yaitu: pendapatan dan belanja/ pengeluarannya.

Anggaran organisasi pemerintahan berbeda dengan anggaran perusahaan dalam 2 hal, yaitu: pertama, penganggaran pada pemerintah dilakukan untuk menganggarkan belanja/pengeluaran pemerintah sedangkan penganggaran pada perusahaan dilakukan untuk menganggarkan laba, dan kedua, efek ratchet pada anggaran perusahaan terkait dengan bonus berbasis pencapaian target laba yang memberi manfaat bagi perusahaan, sedangkan efek ratchet pada anggaran pemerintah terkait dengan kerugian masyarakat akibat pertumbuhan anggaran yang tidak efisien (Lee \& Plummer, 2007).

Penelitian ini berbeda dari penelitian Lee dan Plummer (2007), yakni penyusunan 
anggaran tidak hanya mencakup penganggaran belanja/pengeluaran, namun mencakup analisis penganggaran pendapatan (revenue forecast) dan pembiayaan. ${ }^{5}$

\section{Hipotesis Penelitian}

\section{Efek Ratchet pada Penganggaran Pendapatan}

Pemerintah Daerah

Penganggaran PAD adalah proses penentuan target pendapatan (revenue forecast) yang dilakukan dengan mempertimbangkan: 1) peraturan terkait objek pendapatan spesifik (UU, PP, Perda), 2) data potensi pajak dan retribusi daerah, dan 3) tren proporsi penerimaan pajak dan retribusi serta hasil kekayaan daerah yang dipisahkan selama periode tertentu (realisasi tahun anggaran sebelumnya). Penentuan target pendapatan pemerintah mengalami banyak kendala berupa bias dan kesalahan (error) sehingga target pendapatan dapat ditentukan lebih tinggi (overforecast) atau lebih rendah (underforecast) dari kapasitas fiskal yang sebenarnya, tergantung pada tujuan kebijakan yang ingin dicapai oleh politisi (Voorhees, 2006). Ketergantungan yang tinggi atau tekanan anggaran yang besar merupakan insentif bagi eksekutif untuk menentukan target pendapatan yang lebih rendah (underforecast) dari kapasitas fiskal yang sebenarnya (Marlowe, 2009; Voorhees, 2006).

Hampir seluruh pemerintah daerah di Indonesia mengalami kondisi ketergantungan tinggi yang membuat pemerintah daerah memerlukan instrumen yang baik untuk mengelola keuangan daerah tersebut (Ritonga, Clark, \& Wickremasinghe, 2012). Eksekutif cenderung menentukan target lebih rendah

\footnotetext{
${ }^{5}$ UU No 17 Tahun 2003 Tentang Keuangan Negara, UU 33 Tahun 2004 Tentang Perimbangan Keuangan Pusat dan Daerah dan PP 58 Tahun 2005 Tentang Pengelolaan Keuangan Daerah
}

(underforecast) pada komponen pendapatan (Marlowe, 2009). Peningkatan target pendapatan pada tingkat tertentu dari basis realisasi pendapatan tahun sebelumnya memberi legitimasi bagi pemerintah untuk meningkatkan belanja/pengeluaran pada tahun berikutnya. Hal demikian disebut sebagai pro cyclical ratchet dalam anggaran (Marlowe, 2009). Berdasarkan uraian tersebut, hipotesis pertama penelitian ini adalah sebagai berikut: H1: Terjadi efek ratchet dalam penganggaran
Pendapatan Asli Daerah

\section{Efek Ratchetpada Penganggaran Belanja Daerah}

Komponen belanja daerah dalam APBD terdiri dari: Belanja Langsung dan Belanja Tidak Langsung. Belanja langsung adalah belanja yang terkait langsung dengan pelaksanaan kegiatan dan dapat diukur dengan capaian prestasi kerja yang telah ditetapkan. Agen memiliki insentif untuk bersikap oportunistik dalam penganggaran belanja/pengeluaran dengan meningkatkan perkiraan anggaran periode selanjutnya. Dalam kondisi tertentu, peningkatan anggaran belanja periode selanjutnya mengakibatkan pertumbuhan anggaran yang tidak efisien (Lee \& Plummer, 2007; Marlowe, 2009).

Perubahan anggaran berdasarkan perubahan waktu menjadi landasan penetapan anggaran. Peningkatan atau penurunan anggaran periode selanjutnya ditentukan dengan dasar capaian/varian anggaran yang terjadi pada periode berjalan (Bouwens \& Kroos, 2011; Fisher et al., 2002; Lee \& Plummer, 2007; Marlowe, 2009). Kecenderungan perilaku oportunistik dalam anggaran belanja/pengeluaran pemerintah ditunjukan dengan kecenderungan respons yang lebih besar terhadap varian positif (overspending) dibanding varian negatif (underspending) sebagai basis dalam 
penentuan anggaran berikutnya (Lee \& Plummer, 2007). Dengan demikian, varian positif maupun negatif dalam belanja/pengeluaran pemerintah cenderung menghasilkan peningkatan anggaran periode berikutnya. Sehingga, anggaran belanja/pengeluaran pemerintah cenderung meningkat dari waktu ke waktu (Marlowe, 2009). Berdasarkan uraian tersebut, hipotesis kedua penelitian ini adalah:

\section{H2: Terjadi efek ratchet dalam penganggaran Belanja Langsung}

\section{Metoda Penelitian}

\section{Jenis dan Sumber Data}

Jenis data yang digunakan dalam penelitian ini adalah data sekunder. Data keuangan pemerintah daerah dalam penelitian ini diperoleh dari LKPD Pemerintah Provinsi Daerah Istimewa Yogyakarta. Periode pengamatan penelitian ini dimulai sejak tahun 2012-2015. Landasan penentuan periode pengamatan penelitian ini adalah perubahan peraturan pengelolaan keuangan daerah dengan terbitnya Permendagri No 21 Tahun 2011 yang didasari perubahan peraturan mengenai Pajak Daerah dan Retribusi Daerah (UU 28 Tahun 2009) yang terkait dengan variabel penelitian ini. Teknik pengambilan sampel dilakukan dengan cara purposif sesuai dengan kebutuhan data penelitian.

\section{Populasi dan Sampel}

Populasi penelitian ini adalah seluruh SKPD yang ada di Pemprov Daerah Istimewa Yogyakarta. Jumlah keseluruhan SKPD yang ada di lingkungan Pemprov Daerah Istimewa Yogyakarta berjumlah 31 SKPD. SKPD yang memiliki komponen Pendapatan Asli Daerah (PAD) dalam struktur anggarannya berjumlah 17 SKPD dan SKPD yang memiliki komponen
Belanja Langsung dalam struktur anggarannya sebanyak 28 SKPD.

\section{Model dan Pengukuran Variabel}

Efek Ratchet dalam anggaran pemerintah provinsi daerah Istimewa Yogyakarta diukur dengan menggunakan model yang dikembangkan oleh Weitzman (1980) dan dimodifikasi oleh Marlowe (2009) sebagai berikut:

$$
\begin{aligned}
\left(\mathrm{B}_{\mathrm{t}}-\mathrm{B}_{\mathrm{t}-1}\right) / \mathrm{B}_{\mathrm{t}-1}= & \alpha{ }_{0} / \mathrm{B}_{\mathrm{t}-1}+\alpha_{1} \mathrm{U} / \mathrm{B}_{\mathrm{t}-1}+\lambda^{+} \\
& \left(\mathrm{A}_{\mathrm{t}-1}-\mathrm{B}_{\mathrm{t}-1}\right) / \mathrm{B}_{\mathrm{t}-1}+ \\
& \lambda-\mathrm{Ut}^{*}\left(\mathrm{~A}_{\mathrm{t}-1}-\mathrm{B}_{\mathrm{t}-1}\right) / \mathrm{B}_{\mathrm{t}-1}
\end{aligned}
$$

Keterangan:

Bt : Anggaran tahun berjalan

Bt-1 : Anggaran tahun sebelumnya

A t-1 : Realisasi Anggaran tahun sebelumnya

$\alpha_{0} \quad$ : Koefisien kenaikan anggaran yang tidak dipengaruhi varian positif anggaran tahun sebelumnya

$\alpha_{1}$ : Koefisien penurunan anggaran yang tidak dipengaruhi varian negatif anggaran tahun sebelumnya

$\lambda^{+}$: Koefisien ratchet underforecast/overspending

$\lambda^{-}$: Koefisien ratchet overforecast/underspending

Variabel anggaran dalam model penelitian ini adalah anggaran sebelum perubahan. Anggaran sebelum perubahan merupakan pernyataan perencanaan pemerintah daerah mengenai target ketercapaian kinerja tahun berjalan berdasarkan realisasi atau capaian kinerja anggaran pada tahun sebelumnya. Metode analisis dan pengujian hipotesis penelitian ini dilakukan dengan menggunakan analisis regresi linier berganda yang mengacu pada model penelitian. Penggunaan regresi linear mensyaratkan pemenuhan uji asumsi klasik yaitu uji normalitas, heteroskedastisitas, multikolinieratias dan uji autokorelasi. 
Efek Ratchet pada Anggaran Pemerintah Daerah

\section{Hasil dan Pembahasan}

Tabel 4

Hasil Analisis Regresi

\begin{tabular}{|c|c|c|c|}
\hline \multirow{4}{*}{ Variabel Independen } & \multirow{4}{*}{$\begin{array}{c}\text { Tanda } \\
\text { Prediksian }\end{array}$} & $\begin{array}{c}\text { Efek Ratchet } \\
\text { Pendapataan (PAD) }\end{array}$ & $\begin{array}{l}\text { Efek Ratchet } \\
\text { Belanja (BL) }\end{array}$ \\
\hline & & Model 1(H1) & Model 2(H2) \\
\hline & & Koefisien & Koefisien \\
\hline & & (t-statistic) & (t-statistic) \\
\hline \multirow{2}{*}{$\alpha_{0} / B_{t-1}$} & \multirow{2}{*}{$?$} & 9945368 & 114476699 \\
\hline & & $(2,049)^{* *}$ & $(0,351)$ \\
\hline \multirow{2}{*}{$\alpha_{1} / B_{t-1}$} & \multirow{2}{*}{$?$} & 10196893 & 210582753 \\
\hline & & $(0,972)$ & $(0,539)$ \\
\hline \multirow{2}{*}{$\lambda^{+}\left(\mathrm{A}_{\mathrm{t}-1}-\mathrm{B}_{\mathrm{t}-1}\right) / \mathrm{B}_{\mathrm{t}-1}$} & \multirow{2}{*}{+} & 0,829085 & 0,617 \\
\hline & & $(5,545)^{* * *}$ & $(2,086)^{* *}$ \\
\hline \multirow[b]{2}{*}{$\lambda-\mathrm{U}^{*}\left(\mathrm{~A}_{\mathrm{t}-1}-\mathrm{B}_{\mathrm{t}-1}\right) / \mathrm{B}_{\mathrm{t}-1}$} & \multirow[b]{2}{*}{+} & $-0,156434$ & 0,446 \\
\hline & & $(-0,404)$ & $(2,009)^{* *}$ \\
\hline $\mathrm{N}$ & & 68 & 84 \\
\hline $\mathrm{R}^{2}$ & & 0,704 & 0,143 \\
\hline $\operatorname{Adj} R^{2}$ & & 0,579 & 0,111 \\
\hline F value & & $(5,614)^{* * *}$ & $(4,486)^{* * *}$ \\
\hline
\end{tabular}

${ }^{* * *}$ signifikan pada level 0,01

Hasil analisis memperlihatkan bahwa efek ratchet muncul dalam anggaran Pendapatan Asli Daerah (PAD). Temuan ini memperlihatkan perilaku penyusun anggaran yang meningkatkan target anggaran PAD tahun berjalan berdasarkan ketercapaian anggaran PAD tahun sebelumnya. Temuan ini juga menunjukkan kecenderungan perilaku penyusun anggaran untuk menetapkan target pendapatan lebih rendah dari kapasitas fiskal yang sesungguhnya (underforecast) pada tahun berjalan (slack). Kecenderungan demikian merupakan bentuk bias perilaku yang menjadi kendala penerapan anggaran berbasis kinerja (performance based budgeting) di lingkup pemerintah daerah di Indonesia.
Hipotesis kedua penelitian yang menyatakan bahwa efek ratchet terjadi dalam penganggaran Belanja Langsung terdukung secara statistik. Hasil analisis dalam penelitian ini menunjukkan bahwa capaian kinerja anggaran belanja langsung tahun sebelumnya cenderung lebih rendah dari anggaran (underspending). Hal tersebut mengindikasikan adanya asymmetric ratchet yang dapat diartikan bahwa varian negatif anggaran tahun sebelumnya mendapatkan respons lebih besar dari perencana anggaran sebagai determinan dalam penentuan anggaran periode berjalan dibandingkan varian positif anggaran tahun sebelumnya. 


\section{Simpulan dan Saran}

\section{Simpulan}

Hasil penelitian menunjukkan bahwa efek ratchet terjadi dalam 2 komponen $\mathrm{APBD}$, yaitu Pendapatan Asli Daerah (PAD) dan komponen Belanja Langsung. Temuan mengenai efek ratchet dalam penganggaran PAD berimplikasi bahwa model penetapan target anggaran pendapatan di lingkup pemerintah daerah masih memberi insentif bagi penyusun anggaran untuk berperilaku oportunistik atas asimetri informasi tentang kapasitas fiskal suatu daerah.

Hasil analisis mengenai efek ratchet pada komponen belanja langsung menunjukkan bahwa capaian kinerja anggaran belanja langsung tahun sebelumnya cenderung lebih rendah dari anggaran (underspending). Hal tersebut mengindikasikan adanya asymmetric ratchet yang berarti varian negatif anggaran tahun sebelumnya mendapatkan respons lebih besar dari perencana anggaran sebagai determinan anggaran periode berjalan dibandingkan varian positif anggaran tahun sebelumnya.

\section{Saran}

Penelitian ini mengusulkan beberapa saran agar penelitian selanjutnya dapat menggunakan lingkup penelitian yang lebih luas, baik lingkup cluster, regional, maupun tingkat nasional dan mengembangkan pengukuran variabel penelitian yang memiliki validitas lebih baik bagi tujuan keterbandingan amatan antar periode. Penelitian selanjutnya dapat menggunakan pendekatan yang lebih komprehensif dalam mengukur bias perilaku penyusun anggaran dengan menggunakan metode campuran (mixed method) dan eksperimen untuk mendapatkan gambaran yang utuh mengenai bias perilaku dalam penyusunan anggaran.

\section{Daftar Pustaka}

Abdullah, S. \& Afrah, J., 2016, 'Bukti empiris pengaruh budget ratcheting terhadap hubungan antara pendapatan sendiri dan belanja daerah pada kabupaten/kota di aceh', Modus 28(2), 185-201.

Abdullah, S. \& Nazry, R., 2015, 'Analisis varian anggaran pemerintah daerah penjelasan empiris dari perspektif keagenan', Jurnal Samudra Ekonomi dan Bisnis 6(2), 272-283.

Akbar, R., Pilcher, R. \& Perrin, B., 2012, 'Performance measurement In Indonesia: The case of local government', Pacific Accounting Review 12(3), 262 - 291.

Anthony, R.N., Govindarajan, V., Hartmann, F.G., Kraus, K. \& Nilsson, G., 1998, Management control systems (Vol. 9), Irwin McGraw-Hill Boston, MA.

Aranda, C. \& Arellano, J., 2010. 'Ratcheting effect and the role of relative target setting', Working Papers, University of Navarra, Spain.

Bawono, I.R., Halim, A. \& Lord, B., 2012, 'Public sector performance measurement and budget allocation: An Indonesian experiment', artikel dipresentasikan di the 6th NZ Management Accounting Conference, New Zealand.

Bouwens, J. \& Kroos, P., 2011, 'Target ratcheting and effort reduction', Journal of Accounting and Economics 51(1), 171-185.

Brennan, G. \& Buchanan, J.M., 1977, 'Towards a tax constitution for Leviathan', Journal of Public Economics 8(3), 255-273.

Chow, C.W., Cooper, J.C. \& Haddad, K., 1991, 'The Effects of pay schemes and ratchets on budgetary slack and performance: A multiperiod experiment', Accounting, Organizations and Society 16(1), 47-60. 
Cooper, D. R. \& Schindler, P. S., 2011, Business research methods, McGrawHill/Irwin.

Fisher, J. G., Frederickson, J. R. \& Peffer, S. A., 2002, 'The effect of information asymmetry on negotiated budgets: An Empirical investigation', Accounting, Organizations and Society 27(1), 27-43.

Fisher, J.G., Frederickson, J.R. \& Peffer, S.A., 2006, 'Budget negotiations in multi-period settings', Accounting, Organizations and Society 31(6), 511-528.

Halim, A. \& Abdullah, S., 2010, 'Hubungan dan masalah keagenan di pemerintah daerah', Jurnal Akuntansi Pemerintah 2(1), 53-64.

Hotelling, H., 1990, 'Stability in competition The Collected Economics Articles of Harold Hotelling', Springer, 50-63.

Indjejikian, R., \& Nanda, D., 1999, 'Dynamic incentives and responsibility accounting', Journal of Accounting and Economics 27(2), 177-201.

Lee, T. M. \& Plummer, E., 2007, 'Budget adjustments in response to spending variances: Evidence of ratcheting of local government expenditures', Journal of Management Accounting Research 19(1), 137-167.
Leone, A. J. \& Rock, S., 2002, 'Empirical tests of budget ratcheting and its effect on managers' Discretionary Accrual Choices', Journal of Accounting and Economics 33(1), 43-67.

Mardiasmo, 2002, Serial otonomi daerab: Otonomi dan manajemen keuangan daerah, Andi Publisher, Yogyakarta.

Marlowe, J, 2009, 'Budget variance, slack resources, and municipal expenditures', SSRN Library.

Ndadari, L.W. \& Adi, P.H., 2008, 'Perilaku asimetris pemerintah daerah terhadap transfer pemerintah pusat', artikel dipresentasikan di The 2nd National Conference UKWMS, Surabaya.

Ritonga, I.T., Clark, C. \& Wickremasinghe, G., 2012. 'assessing financial condition of local government in Indonesia: An Exploration', Public and Municipal Finance 1(2), 37-50.

Voorhees, W., 2006, 'Consistent underestimation bias, the asymmetrical loss function, and homogenous sources of bias in State Revenue Forecast', Journal of Public Budgeting Accounting \& Financial Management 18(1), 61-76.

Weitzman, M. L., 1980, 'The "Ratchet Principle" and performance incentives', The Bell Journal of Economics 11(1), 302-308. 